\title{
CORRELATION OF PARITY WITH ABORTION IN RS ST ELISABET BATAM CITY
}

\author{
Omar Sazali Aldy ${ }^{1}$, Ferry Daniel Martinus Sihombing ${ }^{2}$ \\ omarsazalialdy@univbatam.ac.id'1,ferrydaniel.m@univbatam.ac.id ${ }^{2}$ \\ Professional Doctor Study Program, Faculty of Medicine, Batam University ${ }^{1}$ \\ Medical Education Study Program, Faculty of Medicine, University of Batam ${ }^{2}$ \\ Jl. Abulyatama No 5 - Kota Batam
}

\begin{abstract}
Background : Abortion is the threat or release of the product of conception at $\leq 20$ weeks of gestation. In the world there are 20 million cases of abortion every year and 70,000 women die from abortion each year. One of the causes of abortion, among others, parity, maternal age, infectious diseases. This study aims to determine the relationship between parity and abortion.
\end{abstract}

Method : The research method used was an analytic survey with a cross sectional approach. Conducted at ST Elisabeth Hospital, Batam City, the study was conducted for 6 months, all pregnant women recorded in the medical records at Santa Elisabeth Hospital, Batam City, namely 242 pregnant women for the period 2020. Sampling was using total sampling technique with research instruments using checklists. Data analysis using Chi square.

Result : The results showed that most pregnant women with primiparous parity were 126 people (52.1\%). Of the 242 pregnant women, 124 (51.2\%) did not abort and 118 (48.8\%) experienced abortion. Based on the results of the chi-square statistical test analysis, the value of $\rho$ value was 0.002 smaller than $\alpha(0.05)$.

Conclusion : Which means that there is a significant relationship between parity and the incidence of abortion at Santa Elisabeth Hospital. Suggestions to further researchers to be able to expand the research by taking more samples from several other hospitals, in order to strengthen the accuracy of the research results.

Keywords: Parity, Pregnant Women, Abortion

\section{INTRODUCTION}

Abortion is a problem that often occurs in pregnant women. According to the WHO definition, abortion is the loss of a fetus or embryo weighing less than 500 grams is equivalent to about 20-22 weeks of gestation. The younger the pregnancy, the more likely it is to have an abortion. About $75 \%$ of abortions occur before 16 weeks of gestation, and approximately $60 \%$ occur before 12 weeks (Benson and Penoll's, 2009).

In the world there are 20 million cases of abortion each year and 70,000 women die from abortion each year. The incidence of abortion in Southeast Asia is 4.2 million per year including Indonesia, while the frequency of spontaneous abortion in Indonesia is $10 \%-15 \%$ of the 6 million pregnancies each year or 600,000 900,000 , while artificial abortion is around
750,000-1.5 million annually, 2500 of them ended in death (Anshor, 2006)

The frequency of spontaneous abortion in Indonesia ranges from $10-15 \%$. This frequency can reach $50 \%$ if it is taken into account those who are pregnant very early, menstruation a few days late, so that the woman herself does not know that she is pregnant. It is estimated that from 5 million pregnancies per year in Indonesia there are 500,000-750,000 spontaneous abortions, this is a very large number (Sukriani \& Sulistyaningsih, 2010)

Several factors predispose to abortion, such as fetal factors, maternal factors, environmental factors, age, parity, occupation and history of abortion (Myles, 2009). The risk of abortion is higher with increasing parity. Parity one (primipara) is risky because it is not ready both 
medically (reproductive organs) and mentally. Parity above three (grande multipara) will increase the risk of pregnancy and childbirth, because women who often get pregnant or give birth will experience looseness in the uterine wall (Mahdiyah, 2013)

Warton and Fraser and Llewellyn - Jones explained that $25.9 \%$ due to the incidence of abortion could be caused by age and and $39 \%$ due to parity. The incidence of abortion is also thought to have an effect on subsequent pregnancies, both on the complication of pregnancy and on the outcome of the pregnancy itself

Harlap and Shiono in their book Cuningham at all (2006) state that more than 80 percent of abortions occur in the first 12 weeks, and after that this number rapidly decreases. There are various factors that contribute to this situation, namely age and parity. The risk of spontaneous abortion increases with parity and the age of the mother and father. The frequency of clinically detectable abortions increased from 12 percent in women aged less than 20 years to 26 percent in those older than 40 years.

According to data from the Batam City Health Office, the Maternal Mortality Rate (MMR) in Batam is still relatively high, where in 2010 2013 it decreased, namely in 2010 it reached 113.8 deaths per 100,000 live births, in 2011 it reached 78.6 deaths per 100,000 live births. , in 2012 it reached 66.46 deaths per 100,000 live births, in 2013 it reached 53.4 deaths per 100,000 live births, while in 2014 and 2015 the mortality rate has increased, namely in 2014 it reached 111.5 deaths per 100,000 live births and in 2014 it reached 111.5 deaths per 100,000 live births. 2015 in the city has increased, reaching 154 deaths per 100,000 live births. Causes of maternal death include bleeding, hypertension in pregnancy, heart disease, shortness of breath and the rest due to other factors including abortion.

The results of research conducted by Anita (2017) at PKU Muhammadiyah Delanggu Hospital, there was a significant relationship between parity factors and the incidence of abortion where the $\mathrm{p}$ value $(0.007)>0.005$. The variables of age $(\mathrm{p}=0.000)$ and parity $(\mathrm{p}=$ 0.006 ) have $\mathrm{p}<0.05$, so these variables are significantly at risk of spontaneous abortion.
Age has a 12.167 times chance of spontaneous abortion and parity has a 7.490 times chance of spontaneous abortion.

The risk of spontaneous abortion increases with increasing number of parity, age and distance of delivery with subsequent pregnancies. Abortion increases by $12 \%$ in women aged less than 20 years and increases by $26 \%$ at age over 40 years. The incidence of abortion increases if the interval between labor and subsequent pregnancies is 3 months

Based on data from the medical records of Santa Elisabeth Hospital, Batam City, there were 118 (10\%) pregnant women who had abortion cases from January to December from 242 pregnant women.

Based on the above background, the authors are interested in conducting research on "The Relationship between Parity and Abortion at the Santa Elisabeth Hospital, Batam City.

\section{RESEARCH PURPOSES}

This study aims to determine the relationship between parity and the incidence of abortion in RS ST Elisabeth Batam City

\section{RESEARCH METHODS}

The research method used was an analytic survey with a cross sectional approach. Conducted at ST Elisabeth Hospital, Batam City, the study was conducted for 6 months, all pregnant women recorded in the medical records at Santa Elisabeth Hospital, Batam City, namely 242 pregnant women for the period 2020. Sampling was using total sampling technique with research instruments using checklists. Data analysis using Chi square

\section{RESEARCH RESULT}

Based on the results of the study, it was found that the distribution of parity frequency in pregnant women at Santa Elisabeth Hospital, Batam City, namely from 242 pregnant women, most of them were 126 people (52.1\%). And $116(47.9 \%)$ multiparity parity respondents. Of the 242 pregnant women, $124(51.2 \%)$ did not abort and 118 (48.8\%) experienced abortion.

Based on the results of the bivariate analysis obtained. Of the 242 pregnant women with primiparous parity as many as 126 pregnant women of whom 74 had abortion (58.7\%) and 
52 were not aborted (41.3\%), while 116 of them multiparous parity who did not experience abortion were 72 . people $(62.1 \%)$ and those who experienced abortion were 44 people $(37.9 \%)$.

Based on the results of the chi-square statistical test analysis, the value of $\rho$ value was 0.002 smaller than $\alpha(0.05)$, which means that there is a significant relationship between parity and the incidence of abortion at the Santa Elisabeth Hospital, Batam City.

\section{DISCUSSION}

Distribution of the frequency of parity among pregnant women at Santa Elisabeth Hospital, Batam City in 2017, from 242 pregnant women, among them the majority of parity were 126 people $(52.1 \%)$

According to Wikjasastro (1999, in Taharuddin, 2012) every pregnancy that is followed by childbirth will cause abnormalities in the uterus, in this case repeated pregnancies cause damage to the blood vessels in the uterine wall which affects the circulation of fetal nutrients where the amount of nutrients will decrease. compared to previous pregnancies. This theory is also reinforced by Prawirohardjo (1999, in Taharuddin, 2012) that repeated pregnancies (high parity) will stretch the uterus, so that it can cause abnormalities in the location of the fetus and placenta which will ultimately have a negative effect on the health of the fetus and in the delivery process. The impact of abnormalities in the uterus, one of which is the obstruction of nutrition from mother to fetus so that it can cause low birth weight babies (LBW)

One of the causes of bleeding that occurs in the first and second trimesters of pregnancy is abortion. This bleeding can cause the pregnancy to end or the pregnancy can continue. Heavy bleeding can cause shock, perforation, infection and kidney function damage (renal failure) that can threaten the safety of the mother. Death can occur if help is not given quickly and precisely (Prawirohardjo, 2010)

Another theory that supports the results of this study is that it is stated that the first birth (primiparous) usually has a relatively high risk for mother and child, then this risk will decrease at the second and third parity, and will increase again at the fourth parity and beyond.

Abortion that often occurs in the first pregnancy is due to physical factors or social reasons that are not ready to have children, abortion in more than three pregnancies is due to an unhealthy uterine condition, many of the uterine blood vessels have been damaged. Babies born to mothers with high parity have a high risk of abortion because repeated pregnancies cause the uterus to be unhealthy. In this case, repeated pregnancies cause damage to the blood vessels of the uterine wall which affects the circulation of fetal nutrients which will be less than in previous pregnancies, this condition can cause death in the baby.

Abortion is an attempt to end a pregnancy by forcibly removing the results of fertilization before the fetus is able to survive if it is born. Parity is at risk of causing weakness and fatigue of the uterine muscles, so that postpartum hemorrhage tends to occur. If parity is at risk supported by young age and older age, the condition uterine and maternal health is at risk in the occurrence of pathologies in pregnancy, so that it tends to experience prolonged labor, or postpartum bleeding and abortion (Sarwono, 2010).

According to Winkjosastro (2013) from a maternal point of view parity $2-3$ is the safest parity for pregnancy and childbirth, while parity 0.1 and high parity (parity>3) have a higher maternal mortality rate. Parity 0 requires deeper adaptation to accept pregnancy both physically and psychologically while mothers with parity 1 are still in the process of accepting a situation where the mother already has 1 child but must accept the next pregnancy, especially if the pregnancy is too close or too far away

This study is in line with the research conducted by Siti Mulyati at five hospitals in Jakarta in 2003 , found that pregnant women whose parity $<1$ and $>3$ had a risk factor for abortion 1.2 times compared to pregnant women whose parity was $1-3$, but statistically not significant $(\mathrm{p}=0.447)$

This study is not in accordance with the research conducted by Mahdiyah et al (2013) regarding the relationship between parity and the incidence of abortion, the results show that 
most of the incidents of abortion are unsafe parity which is at risk of experiencing abortion, but this is statistically meaningless ( $\mathrm{p}$ - value = $0.562) \mathrm{p}>0.05$, it means that there is no significant relationship between parity and the incidence of abortion. This is because parity is not the main factor causing abortion, there are other factors that were not disclosed in this study.

This research is supported by research conducted by Shofaria (2016) that most of the incidence of abortion is unsafe parity $(0,1$ and $>$ 3 ) which is at risk of experiencing abortion, but this is not statistically significant ( $\mathrm{p}$-value $=$ $0.152)>0.05$ so there is no relationship between parity and the incidence of abortion, so it can be concluded that based on the results of this study, the incidence of abortion was not caused by parity, it could be caused by other risk factors that could not be revealed in this study. Factors that cause abortion are not only caused by one risk factor, because in essence the risk factors are interrelated.

\section{CONCLUSION}

1. Of the 242 pregnant women, most of the primiparous parity was 126 people $(52.1 \%)$.

2. Of the 242 pregnant women, 124 (51.2\%) did not abort and 118 (48.8\%) experienced abortion.

3. Based on the results of the chi-square statistical test analysis, the value of $\rho$ value is 0.002 smaller than $\alpha(0.05)$, which means that there is a significant relationship between parity and the incidence of abortion at the Santa Elisabeth Hospital, Batam City.

\section{SUGGESTION}

1. For Further Researchers

It is hoped that the next researchers will be able to expand the research by taking more samples from several other hospitals, in order to strengthen the accuracy of the research results.

\section{For Health Service Institutions}

It is expected to be able to improve skills and knowledge for health workers such as midwives and obstetricians, such as attending training to update the latest knowledge on health, especially obstetrics and gynecology.

\section{Educational Institutions}

It is hoped that it can collaborate between education and hospitals so that students can apply the knowledge they have gained in lectures.

\section{DAFTAR PUSTAKA}

Astari, Resha. Hubungan Paritas dan Usia Ibu dengan Kejadian Abortus di RSUD Dr. Pirngadi Medan Pada tahun 2010.

Fakultas Keperawatan Universitas Sumatra Utara Tahun. 2013

Ayu Chandranida Manuaba, Ida, dkk. 2009.

Memahami reproduksi wanita. Jakarta : EGC

Badriyah. Hubungan Antara Paritas dengan Terjadinya Perdarahan Post Partumdi Rumah Sakit Arifin Ahmad Pekanbaru Tahun 2010.

Bagus Gde Manuaba, Ida. 1998. Panyakit Kandungan dan Keluarga berencana untuk pendidikan bidang. Jakarta : EGC

Cunningham, Gary F, dkk. 2006. Obstetri Williams Vol.2. Jakarta: EGC

Dorland. 2002. Kamus Kedokteran Edisi 29. Jakarta : EGC.

Eka Yuli Handayani. Hubungan Umur dan Paritas dengan Kejadian Abortus di RSUD Kabupaten Rokan Hulu Tahun 2015.

Fauzi, Ahmad. Lucianawaty, Mercy. Hanifah, Laily. Bernadette, Nur. 2002. Aborsi di Indonesia.

Levono KJ, Cunningham FG, Gant NF, et al. Obstetri Williams. Edisi 21. 2009.

Lukitasari E. Kejadian Abortus Inkompletus yang Berkaitan dengan Faktor Risiko pada Ibu Hamil di RSU. H.M Ryacudu Kotabumi Kabupaten Lampung Utara Tahun 2007-2009.

Mansjoer,Arif,dkk. 2000. Kapita Selekta Kedokteran Edisi ketiga, jilid I, FKUI. Jakarta: Media Aesculapius.

Manuaba, dkk. 2007. Pengantar Kuliah Obstetri. Jakarta: EGC 
Mariani (2012).Faktor-faktor yang berhubungan dengan kejadian Abortus inkomplet di ruang kebidanan rumah sakit Umum daerah dr. Zainoel abidin banda aceh, diakses 03 desember 2013).

Megawati ( 2012). Faktor- faktor yang berhubungan dengan abortus di RSUD dr. Zaonal Abidin banda aceh

Morgan, geri \& Carole hamilton. 2009.

Obstetri \& Ginekologi. Jakarta : EGC.

Nurjaya dkk. Hubungan Paritas dengan Kejadian abortus di RSIA Siti Fatimah Makasar Tahun 2006

Prawirohardjo S. Ilmu Kebidanan Sarwono Prawirohardjo. Edisi IV. Jakarta: Bina Pustaka Sarwono Prawirohardjo; 2008.

Prawirohardjo, sarwono. 2009. Ilmu Kebidanan. Jakarta : PT. Bina Pustaka.

Prawirohardjo, sarwono. 2010. Buku Acuan Nasional Pelayanan Kesehatan Maternal dan Neonatal. Jakarta : PT. Bina Pustaka.

Raden, JN. Hubungan antara Kejadian Abortus dengan Usia Ibu Hamil di RSUD Dr.
Moewardi Surakarta pada tahun 2008.

Fakultas Kedokteraan Universitas

Sebelah Maret Surakrata. 2009.

Saifuddin, Abdul Bahri, 2008. Pelayanan Kesehatan Maternal Neonatal. Jakarta: Yayasan Bina Pustaka Sarwono Prawirohardjo.

Titik Kuntari, Siswanto Agus Wilopo OE. Determinan Abortus di Indonesia.2006

Wani,elda. (2013). Hubungan umur dan paritas dengan kejadian abortus diRSUD Rokan Hulu

World Health Organization. Unsafe Abortion : Global and regional estimates of the incidence of unsafe abortion and associated mortality in 2008. Abortion. 2011

Yusnaini. Hubungan karakteristik ibu hamil dengan kejadian abortus di Ruang Rawat Inap Kebidanan RSD .Raden Mattaher Jambi Tahun 2009. Universitas Batanghari Jambi.2010. 